\title{
Fevers, Movements, Passions and Dead Cities in Northern Goiás
}

André Dumans Guedes

\begin{abstract}
In this paper I show how people living in a small town in the Brazilian state of Goiás describe the "economic" processes that have been shaping and transforming their lives over recent decades: the gold fever in the 1980's, the construction of three large hydroelectric plants and the complex relation between this city and the mining company that "created" it. In so doing, I focus on the ideas of movement, passion and fever, looking to demonstrate how such categories relate these processes to other experiences and domains. In pursuing this aim, I also look to establish a counterpoint to the ways through which issues such as the social effects of large development projects or the modernization of "traditional" areas have usually been described in the social sciences.
\end{abstract}

Keywords: popular economies; development; movements; economic fever; dams; gold mining

\section{Resumo}

Neste artigo, mostro como os habitantes de uma pequena cidade localizada no estado brasileiro de Goiás descrevem os processos "econômicos" que vêm moldando e transformando suas vidas ao longo das últimas décadas: a febre do ouro dos anos 1980, a construção de três usinas hidrelétricas e a complexa relação existente entre a cidade e a mineradora que "criou" esta última. Para tanto, eu foco aqui nas ideias de movimento, paixão e febre, buscando mostrar como tais categorias relacionam tais processos a outras experiências e domínios. Dado este objetivo, busca também estabelecer um contraponto às maneiras através das quais são descritos, nas ciências sociais, tópicos como 
os efeitos sociais de grandes projetos de desenvolvimento ou a modernização de áreas "tradicionais".

Palavras Chave: economias populares; desenvolvimento; movimentos; febres econômicas; barragens; garimpo 


\title{
Fevers, Movements, Passions and Dead Cities in Northern Goiás
}

\author{
André Dumans Guedes
}

... and then I saw this station, these men strolling aimlessly about in the sunshine of the yard. I asked myself sometimes what it all meant. They wandered here and there with their absurd long staves in their hands, like a lot of faithless pilgrims bewitched inside a rotten fence. The word 'ivory' rang in the air, was whispered, was sighed. You would think they were praying to it. (...) And outside, the silent wilderness surrounding this cleared speck on the earth struck me as something great and invincible, like evil or truth, waiting patiently for the passing away of this fantastic invasion.

Joseph Conrad - Heart of Darkness

A "town of pensioners", a town closing down, a stilled or dead place: this was how my interlocutors would invariably describe the location where I had gone to conduct my fieldwork: the town of Minaçu, situated in the north of the Brazilian state of Goiás, an area of the country that began to be populated systematically from the middle of the twentieth century. Such comments would typically lead to digressions about the events there over the last two decades, after the construction of three large hydroelectric dams made it impossible to extract any more gold from the mines (garimpos) located along the river courses. Deserted streets, closed houses, rundown and derelict buildings: no shortage of evidence existed that the town in question had indeed seen busier (mais movimentados) and more agitated days in the past during both the mining era and the time when the hydroelectric dams were under construction 
Most of the people I met there had once worked in mining or related activities. If they still lived in Minaçu, it was partly because they lacked the means to walk away and try their luck elsewhere after this work had vanished. There was little left to do except wait (esperar) without much hope (esperança): ${ }^{1}$ either for highly unlikely financial compensation for the losses caused to them by the dams, or for the arrival of new companies reinjecting some movement into the town, or for some kind, any kind, of initiative from politicians - just as improbable - that could help them to walk on their own two feet again. In the meantime, jobless and at a standstill, they lived off minimum income programs ${ }^{2}$ and retirement pensions, occasional odd-jobs or the food baskets distributed by a social movement formed in the region to defend the rights of those affected by the dams.

By presenting their situation to me in this way, local people never ceased to challenge some of my preconceptions concerning the difficulties experienced by those "people affected by dams" in general. After all, since the mid-1980s innumerable studies across a wide range of disciplines have devoted themselves to analyzing the social impacts of hydroelectric dams in Brazil. ${ }^{3}$ For several years I myself had worked on these issues both as an academic and as a consultant for the social movement cited above. Indeed it was partly due to this background that I had decided to carry out the fieldwork for my doctoral thesis in Minaçu.

In the vast majority of these studies, and likewise in the campaigns fought by those affected by the dams, the drama experienced by the latter population is presented mainly in terms of "compulsory relocation": the forced migration of populations living in the areas where these projects have been implemented. However, going by what people told me in Minaçu, things there took on another guise: unable to walk away and made keenly aware of the sedentary and captive lives of those who depend on the help

\footnotetext{
1 L'Estoile's observation (2014: 13) concerning the verb esperar can also be applied to this context: as he notes, the term fuses the ideas of 'expecting,' 'waiting' and 'hoping.'

2 These programs involve financial resources transferred monthly by government bodies at federal or state levels to people classified as poor.

3 In the 1980s works by Marazzarollo (2003 [1980]), Sigaud (1988), Sigaud et al. (1987) and Grzybowski (1987) anticipated and inspired research studies that would multiply exponentially from the mid-199os. For a partial review of the existing literature, see Magalhães (2007). Consolidation of this field was attested by the organization in Belém, at the end of 2010, of the III National Encounter of Social Sciences and Dams, held in parallel with the II Latin American Encounter of Social Sciences and Dams, bringing together more than 200 works by Brazilian, Latin American, U.S. and European researchers.
} 
of the government and other institutions to survive, my interlocutors experienced a kind of "compulsory immobility".

The background formed by these kinds of incongruences provides the basis for my analysis of various categories central to these people (e.g. movements, passions and fevers). Here I am interested in exploring the specific ways through which they reflect on the changes that have marked their lives over recent years - the agitation of the past giving way to the lack of movement of the present, for example. These reflections offer another perspective for investigating universes that, from the viewpoint of the literature relating to dams or even of our intellectual common sense, are being "affected" and brutally transformed by "economic" and "modernizing” processes. Here I do no more than try to pursue the traditional anthropological injunction to respect the native point of view, attributing my interlocutors "a measure of authority in producing an understanding of their life-worlds" (Englund \& Leach 2000: 226-7).

\section{Cursed money and holy nuggets}

Given the hardships of the present, the gold digging era is remembered with affection and melancholy. ${ }^{4}$ At the same time, though, the money obtained in mining was not infrequently said to be "damned" or "cursed", especially as money that never stops in people's hands.

It never stops, some miners say, since it tends to be spent almost immediately on sprees, binges (farras) and various other temptations. Others say that the money vanishes because the eagerness for more profits encourages reinvestment of capital in the mine, where the money obtained often seems to vanish in mysterious ways. Moreover, in the complicated context in which I got to know them, some miners seemed to share the kind of criticisms formulated by opponents of mining activity - frequently describing it as dishonest or non-serious work: wealth too easily obtained and thus destined to vanish just as easily. The "curse" in this sense is punishment for those who think that they can advance in life rapidly without hard or decent work - without merit. As a starting point to this discussion,

4 Although a vast bibliography exists on mining in Brazil in general, few ethnographies specifically focus on this topic: among the exceptions we can highlight the works of Cleary (1992) and Laretta (2012). 
we should note that references to "cursed money" are also common among groups who, like miners, are often subject to moral condemnations and who live off an irregular and inconstant flow of resources: transvestites, for instance (Garcia 2008: 250) or drug traffickers (Zaluar 2004) and prostitutes (Almorin et al. 2010: 119).

However we need to pursue the question further. While these accusations are undoubtedly widespread and taken seriously, they far from exhaust everything that the miners have to say about the mobility and movements of resources and wealth. Firstly my interlocutors know very well that money's exceptional volatility is not limited to the mining industry, and they would undoubtedly concur with the rural workers of the Zona da Mata region of Pernambuco described by L'Estoile (2014: 21). For the latter, "money [...] is seen as utterly unreliable. In the experience of the poor, money withers away fast. The general expectation is that, if one happens to earn money, one spends it immediately". In the case studied by L'Estoile too, therefore, they are frequent "stories of people who, having received significant amounts of money, spent it, and became as poor as before" (2014: 22).

This helps explain the salience of the contrast made between this "cursed money" and the gold nuggets that remain still from the mining era, which, some say, "seem holy". Not by chance they were customarily given as presents by miners to their children, forever concerned "to leave something" for them. The physical attributes of the nuggets - which justify or reinforce the cultural meanings attached to these objects - explain why they were ideal for performing the role of heirlooms to leave for one's offspring, just as they make explicit how these distinct resources, with their different propensities to move about, are preferentially associated with particular spaces. On one hand we have money or gold dust whose "liquidity" enables their rapid transformation into anything else (drink, clothes, presents...) and spent in the cabarés (strip clubs and brothels) or any other corner of the rua (street), moving very easily, becoming frittered away and lost. On the other hand we have the nugget - solid, hard and durable - which must be carefully hidden away (mocozada): preferably by a woman and ideally inside the home.

Even today, therefore, adult men and teenagers can be overheard asking women (their wives or mothers) to safeguard and store their resources - "if I keep hold of it, I spend everything..”. Even things as solid as nuggets seem to become slippery and elusive in male hands, a fact shown by the many 
stories in which the lumps fall back into the river or vanish from the pocket of a miner's shorts while diving in the water, as though wanting to return from where they came. Likewise the use of gold teeth, a frequent practice among miners, is intended to confer durability and permanence to the gold, preventing its dissipation by keeping it bound to the body (and far from the miner's hands where money never stops).

For many people these nuggets are not envisaged as savings or a reserve, something that could eventually be transformed into money through sale. Frequently they are conceived rather as something that must be kept forever, both by givers and receivers. "No way lad! I'll never give away or sell this nugget, even if I'm strung up to die, it will stay with me". Experiencing considerable financial difficulties with no money left for food, Altino and his wife went so far as to "scrape the copper" off old mining equipment to obtain a little income. Even so they never once considered selling the nuggets they had given to their two children, still young, which could have been sold for a relatively high price.

These nuggets could be said to represent, then, the kind of "fixed points, realities that are exempted [...] from the exchange of gifts or from trade" described by Godelier (2001: 17) who also reminds us that Mauss had already highlighted the existence of two types of copper among the Kwakiutl, the most important being items that "do not go outside of the family" (ibid: 54). Moreover, as objects excluded from circulation, these nuggets seem to affirm "the existence of identity differences between individuals" (ibid: 54), male giving contrasted with female keeping (cf. Weiner 1992), where the physical limits of the house signal those "conversion thresholds" analyzed by Guyer (2011: 2215), "often implicating different moral economies". The comparison with L'Estoile (2013: 22) is also instructive: while in the case studied by myself, money's fluidity is contrasted with the duration and durability of the parental relationship with children, in the case described by the author, money - "essentially short-term and fugitive" - is contrasted with friends "valued as a long-term resource: friendship is a personal relation, which is supposedly stable over time". The references to "cursed money" can thus be conceived in light of these "moral assessments of certain adjectivally marked moneys - dirty money, hot money, bitter money, money that burns like oil, 'liquid' money - [derived] from those money's positions as hinges between short-term and long-term transactional orders (Maurer 2006: 24)”. 
But while examples of contexts where money is rapidly consumed are far from rare - indeed its volatility or liquidity sometimes appears inherent why should it be qualified as "cursed"? Referring to the tropeiros (muleteers) of the end of the seventeenth century, Buarque de Holanda (1994: 152-4) emphasizes how they lacked the "rationalizing asceticism" so typical of the bourgeois ideal: these "rustic men" were known for a "love of luxury and the pleasures", evident in how they spent all their earnings on brothels (cabarés), gambling, the theatre or decorating their horses with precious metals. In relation to the miners, Cleary (1992: 123) stresses that in the region of Eastern Amazonia studied by himself and beyond, "the stories that [they] most enjoy recounting and hearing are tales of how the profits from a bonanza were spent. The more spectacular the extravagance, the greater the esteem with which the story is held". The references to the notorious "consumerism" of the work site labourers or peões do trecho - who I shall introduce to the reader below - are also as old as the references to them in the literature, in various cases pervaded with a reproachful tone from the author concerned. Is there, then, some particularity that marks and interconnects contexts like these, whose notoriety arises precisely from the excessive "squandering" of money and "extravagant" forms of consumption?

\section{Times of fever and passion}

While the references to "cursed money" may be used to morally condemn the behaviour of oneself or others, it is also undeniable that the accounts of the mining era are permeated by other modulations: by the passion and the fervour, for example, elicited even today by the memory of experiences in the past. Initial caution and reticence are gradually abandoned as enthusiasm engulfs the speaker and makes him forget or overlook what might ever be reprehensible in his behaviour... How not to become excited and agitated with the narrative of those busy days of the past, during the gold fever?

In the academic or native descriptions of mining, the term "fever" is commonly used to explain the dynamic unleashed by the discovery of goldrich areas that overnight start to attract a large influx of people. Cleary

5 The tropeiros led the trains (tropas) of pack animals that plied the route between diverse centres of commercial production and consumption during Brazil's colonial era (and up until a few decades ago in regions like Goiás discussed here). 
(1992: 27) emphasizes, for example, that "most of the historical literature on gold mining in colonial Brazil [...] often seems little more than the record [of these] rushes" which erupt and vanish "just like the repeated outbreaks of malarial fever". Cleary's image here in fact echoes my interlocutors' own familiarity with the disease and the association with the idea of the gold rush: both gold fever and malaria begin suddenly and quickly peak before vanishing completely soon after, probably to re-emerge at another time or place, following the same pattern.

However it should be emphasized that, for my interlocutors, the economic dynamics evoked by the idea of fever are not exclusive to gold mining. Back in the mid-197os, before the town was invaded by miners attracted to gold ore, it was casseterite that triggered an intense and rapid influx of outsiders into Minaçu. Then, from the 1980 s onwards and to a large extent overlapping the gold mining activity, it was the dam construction works - Serra da Mesa, Cana Brana and finally São Salvador - that moved the town. Casseterite fever, gold fever, dam fever: all these cases involve processes that, from the native viewpoint, converge in many aspects.

Characterized by the particular modes through which they intensify agitation and movement, the times and spaces of the fevers are marked, therefore, by a number of traces that manifest more or less independently of the specific nature of the productive activity. On a very general level, and without any pretence to exhaust the subject, we could cite: a) a predominantly male population, caused by the arrival of outsiders attracted by the opportunities enabled by the fever, including the possibility of making relatively quick money; $b$ ) the huge number of cabarés (strip clubs), brothels and gambling houses opened to cater for this public (many of these businesses also being "mobile", "circulating" through different areas); c) the rapid multiplication of a rich spectrum of small and medium-sized businesses and services, both formal and informal, "local" or "outside", offering goods and services to this affluent population or to support the productive activity responsible for setting off the fever; d) a peculiar pattern of "urbanization" in which temporary buildings, encampments and accommodations overlap the previously existing "provisional" nature of "popular" spaces and ways of life (that very often appear more stable merely in comparison to this pattern); and e) a reorganization of the wider regional economic flows as an outcome of the 
relatively brusque changes in the kinds of goods traded, the patterns of supply and demand, and the price structures.

Here it is important to emphasize that these dynamics and processes are not and cannot be confined to Minaçu: the very character of fever, as we have seen, presumes the need for it to be apprehended transcontextually and in a relatively abstract form. We are dealing, therefore, with a transitory phenomenon actualized through a diverse range of productive activities, which for this reason are also present in all kinds of places. Though not entirely adequate, the term "circuit" may provisionally serve to evoke a set of geographic locales or areas that become particularly frequented or targeted due to the fact that such "fevers" have irrupted (or are about to irrupt) there. ${ }^{6}$

It needs to be remembered that, for my interlocutors, fever refers not only to a specific socioeconomic dynamic, but equally to a passion. The agitation and frenzy that swept through the region after the announcement of the gold find seems to have affected those living there too. A feverish town, feverish bodies and hearts, hot-headed and disturbed spirits... Fever in both cases (and in relation to malaria) refers to a movement that is not only sudden and temporary, but also marked by very particular intensities, where the broader process that contaminates and moves the localities is replicated in the persons, bodies and lives swept up by it. Altino, today blefado e rodado,7 recalls with shining eyes how he "fell in love with mining": "night after night at the foot of the mine, I really liked that a lot, it was a real passion, you've no idea just how. The miner can't walk away from mining so easily. It's an addiction..."

It should be noted that the desire to mine gold is intrinsically associated in these accounts with an equal "lack of control" in consuming the wealth

6 Souza Martins (1998: 690) mentions the "waves of revolts of superficial modernization" that struck towns like Pedro Afonso and Miracema do Norte, a little further to the north and on the shores of the same Tocantins River discussed here: "for a long time regions left to stagnate after the transitory experience of being on the frontier during construction of the Belém-Brasilia highway". On fever in the context of large-scale hydroelectric, mineral, metallurgic and farming projects, and considering only those regions specifically familiar to my interlocutors, see Nunes (1985), Antonaz (1986), Gaspar (1990), Aquino (1996), Vieira (2001) and Rumstain (2008) for example, as well as the aforementioned Souza Martins (1998). The theme is a constant in the literature on gold mining: the best ethnographic reference in this respect is the work by Cleary (1992). Largely converging with popular conceptions of the subject, the theme of fleeting wealth followed by decline is also heavily emphasized in the historiography of Goiás state. "Goiás, despite its apparent and though short prosperity, was never much more than a stopover for adventurers who abandoned the place as soon as the mines showed signs of exhaustion" (Palacin \& Moraes 2008: 73; also see Estevam 2004, and Póvoa Neto 1998 for a critique of these formulations).

7 Blefado e rodado: without money or direction in life, and continually drunk. 
obtained. This "lack of control" can also be elucidated in the references to the controlados, the "controlled ones": those who have been able to control themselves and economize. Not coincidentally, the latter include some who today number among Minaçu's richest men - and who, though becoming rich through mining, nonetheless managed to escape the "vicious circle" in which miners usually become embroiled. In the case of these controlados, the resources acquired through mining were invested in other activities where medium or long-term capital accumulation is perceived to be more viable (money lending or commerce, for example). At the same time, the ambition for gold is not accompanied in this case by the other kinds of "lack of control" that lead, precisely, to the dissipation of wealth. We could suggest that, for the controlados, something prevailed similar to what Hischman (1979) called the "principle of the countervailing passion" - which, confronting and curbing more harmful passions, explains the legitimacy of avarice and the consequent constitution of the "spirit of capitalism". For the miners among whom I lived, however, it seems that one passion ("extract more and more and more", "dig, dig") did not serve as a "civilizing medium" or "counterweight" (Hirschman 1979: 25; 33) to others ("spend, spend"). Much the opposite: the latter seem to have been sharpened or intensified by the feverish search for gold. It is unsurprising, then, to note the essential role played in tales of mining by the references to women, prostitution, gambling, drugs, alcohol, cigarettes - with all these elements frequently combining in practices like the fechar cabaré, "closing the brothel". ${ }^{8}$

Moreover the fact that the climate of the fever appears ideal for those who want to fritar or "fry" their heads perhaps helps explain something that always struck me as unusual: not just that cocaine was consumed far more than marijuana among my acquaintances, but also that harsher moral sanctions were demanded for the latter than the former. Though amplified, there are undoubtedly limits to permissiveness during a fever: many cocaine users become offended when accused of consuming marijuana since they primarily associate consumption of the latter drug with the malas or smalltime crooks. The valorisation of cocaine, on the other hand, seems to be

8 "You want to know what closing the brothel means? It's when you join up with some mates, four or five, and each one puts a thousand reais, for example, into the kitty. And then for ten or eleven hours, all the women are there just for you - for us only. And in that house, for that day, nobody else comes in, it's all for us! So the door stays shut until the next day, until the evening, with just us inside". 
directly related to its radicalization - heating, agitating, moving - of the already intense temperatures and velocities of fevers.

However this imbrication of different kinds of "lack of control" - one passion stimulating another passion - is not limited to the world of mining. Indeed fevers are not limited to gold digging: in Minaçu they also erupted during cassiterite mining and during the construction of the hydroelectric dams. Consequently we need to make explicit the relations that approximate - and sometimes render indiscernible - the peões do garimpo (mine labourers) and the peões do trecho (construction site labourers).

Taken broadly, the term trecho - "section" or "tract" - designates the work site and wider reality of the mobile or itinerant labourers employed on a temporary basis in large-scale projects of various kinds, usually located in Brazil's Centre-North region: agroindustrial projects, mineral and metal extraction, hydroelectric plants and infrastructural works. ${ }^{9}$ More generally, anyone who is far from his homeland, moving town and switching jobs with some frequency may be said to be on the trecho - actually a fairly commonplace experience in those parts.

As well as working as miners, the large majority of my interlocutors had also been peões do trecho - many of them employed in the construction of the same dams that had made their work in the gold mines impossible. Others arrived in the town to work on the construction site for the first dam and after a time went into mining. Certainly there is nothing exceptional in such cases: the overlaps between large-scale projects and mining areas are relatively common in some regions (Oliveira 1989, Gaspar 1990). In these cases, one fever "pulls" or combines with others: especially in "frontier" regions, a series of factors contributes - or at least did so until recently - to the opening or reactivation of mining areas in the wake of these projects: a) the prior influx of labour to these areas, swelling the local population; b)

9 In his autobiography - symbolically entitled Urrando no Trecho. Recordações de um Engenheiro de Obras [Howling on Site. Recollections of a Construction Engineer] - Corrêa (2007: 11) provides the only explanation I know for the emergence of the term trecho: "[This term] comes from the big linear highway construction works where it is common practice to divide the total volume of work into lots, allocating them to different construction firms [who are assigned responsibility for different] work sections or trechos. In a casual encounter between workers building the same highway, it is common for one to ask: 'What section [trecho] are you on?' followed by the reply that identifies the firm responsible for the section in question and the kilometres delimiting its section of the highway. The term trecho became propagated outside its initial borders and, as if all of Brazil were one immense building site, came to designate all the large-scale construction projects and the men working on them, the peões do trecho, the 'section labourers,' nomads par excellence and by necessity". 
the installation of infrastructure to support these new inhabitants, thereby facilitating the access to regions that had once been too inhospitable or remote; $\mathrm{c}$ ) the expectations of making relatively easy money in these projects (Lins Ribeiro 1988, 2006), combined with the discovery of the "costs" of these earnings and the observation that they can be obtained without much hierarchy or discipline in the mines.

At the time I first arrived in Minaçu, with the town at a standstill, it had become almost compulsory for many of its residents - especially young men - to leave the area, running or ripping up (rasgando) the trecho in search of busier (mais movimentados) places: the south of the state of Goiás, the hydroelectric plants being constructed in Amazonia, soybean plantations in Mato Grosso, mining areas in Bahia and Tocantins. I have explored this point in more detail in earlier works (Guedes 2012; 2013a), looking to show how professional experience far from home - i.e. on the trecho - is valued as a space of young sociability clearly opposed to the obligations associated with family life..$^{10}$ In their eagerness to enjoy the movement as much as possible - and also to enjoy "while moving" - many of the young men that I met valued being able to work "autonomously" and temporarily much more than a fichado or stable job, periodically changing employer and town - and, if necessary, occupation. What I sought to show in these earlier works were precisely some of the tensions arising from use of these "extraordinary" resources (for example, the extra money obtained working overtime): their uncontrolled and "generous" spending; the efforts of their wives to channel this money into the "home", rather than into worldly spending; the proliferation of barraginhos, children of single mothers "abandoned" by their barrageiro fathers"; the "local" fears concerning the arrival of these "Don Juans", relatively loaded with money and ready to spend. Today the young people who work on the trecho for these different companies have experiences very similar to those enjoyed by their fathers or older brothers

10 On this point, Dias Duarte (1986:177) emphasizes that "the much discussed question of the matrifocality of the working classes, backed by the empirical evidence of a large number of households that survive without the permanent presence of the man and frequently under a succession of different men, can perhaps be better understood from the angle of this male ambiguity that translates into a real and frequent ambivalence, especially during the period of late adolescence, the crucial turning point in male trajectories vis-à-vis the project of obligation".

11 This term refers to the labourers who work on the dam construction sites, who frequently move from one part of the country to another as and when new projects are implemented. 
during the mining era. The tales of the latter and an entire set of ideas and symbols relating to mining thus continue to stimulate new generations to experience the kinds of intensities and movements once conspicuously associated with gold digging.

I am not concerned here with discussing the supposed "causes" of these behaviours. I limit myself to suggesting that the classic potlatch - emphasizing its "honour" dimension more than "credit" (Mauss 1974: 99-101) - may be useful in terms of problematizing the fairly unconvincing "critical" and "anti-capitalist" moralism of authors like Souza Martins $(1988)^{12}$. Rather than adhere to sociological explanations for these motives, it is more productive to follow the movement of native categories, the convergence between what happens in the fever and the trecho, an approach that allows us to distinguish analytically some of the meanings intertwined in the very idea of movement: while what is foregrounded in the case of fever is movement as a kind of agitation or frenzy, what is most evident in the trecho is the dimension of movement as a spatial dislocation or mobility. ${ }^{13}$

Beyond this distinction, it must be emphasized how both the trecho and fever, as situations or contexts marked by the radicalization of movements, also stimulate those who experience them to move, making those things like money - with which they act just as or even more mobile.

From the viewpoint of anthropological production, there is no novelty per se in mentioning these situations where the intensification of certain emotional and bodily states circumscribes specific spaces and times, in vivid contrast to the regularities and forbearance of ordinary or quotidian life. Here, perhaps, we can also locate the importance that Durkheim (2008: 547) attached to the "festival, which through its capacity to put the masses into movement and thus to excite a state of effervescence" approximates the sacred. Mauss (2003: 475) also shows how Inuit societies conceive "winter life as one long celebration" - a radical counterpoint to the "egoism of the individual or the nuclear family" (ibid: 493) characteristic of the summer. Any of my interlocutors who had experienced the fever or the trecho would

12 Writing about the peões do trecho on farming projects in Amazonia, this author (Souza Martins 1998: 6) argues that their talk "is almost always dominated by the logic of merchandise and money, quantities, and imbued by a fascination with the marvellous and unlimited array of things that can be bought and sold", a vocabulary and logic that, he states, "do not belong to the worker but to those who dominate and exploit him".

13 I have paid special attention to this dimension of movement as dislocation in other works (Guedes 2012; 2013a; 2013b) and do not explore the question here therefore. 
agree that there is something (or even much) that is "festive" about the experience. Like the Inuit winter, these are ideal circumstances for the "phenomenon of sexual licence" (ibid: 478) and for the proliferation of "a continual round of communal feasts" (ibid: 494).

However there is no need to journey so far away from Goiás to establish productive comparisons for my present argument. We can turn, for example, to what Dainese (2013:5) has to say about the time of politics in the rural community studied by herself in the interior of Minas Gerais, a few hundred kilometres from where I worked. For the residents of the locality in question, this "time" is also defined by the fact that during it "there is a lot of movement": this is "a moment involving a greater circulation of people, a diversification of events, a transformation of spaces, an outbreak of passion". Not by chance these are the ideal circumstances for the emergence of "a state of affairs called a lack of control". Both in fever and in the time of politics, we seem to be presented with situations involving an "acceleration" of life (Dainese 2013). This comparison is also useful since it affords a counterpoint to the "effervescences" of Durkheim (2008: 547) and the "orgies" of Mauss (2003: 501). Unlike what happens in these circumstances, mining and the time of politics are not exactly celebrations of the "collective" or of established social ties. As we saw above, fever (and likewise the trecho) lead to movements of passion and lack of control that generate tensions, distancing men from their families. Dainese (2013: 11) meanwhile describes how the time of politics offers a perfect occasion for fights, misunderstandings and deaths. Not coincidentally, one of her interlocutors emphasizes that during this period "kinship comes to an end".

But while the similarities between these two situations are striking, we also need to highlight important differences concerning the nature of the temporalities involved. The "time of politics" mentioned by Dainese is explicitly inscribed in the line of research developed by Palmeira (2001). The latter, according to Dainese herself, shows how "the organization of social life into times - [...] time of politics, time of festival, time of harvest implies another pace to activities and behaviours" (Dainese 2013: 5). Hence, in terms of this or that "appropriate time for the performance of particular activities deemed important by society" (Palmeira 2001: 173), we are dealing with variations that, like those considered by Mauss (2003), could be called "seasonal". The alternation, duration and succession of these times are thus 
minimally regulated by specific parameters that, in the end, induce a degree of order and predictability, contributing to a relative "control" of these movements and passions. As we shall see later, though, in terms of the fevers, things do not unfold exactly in this way.

\section{Towns that stop, come to an end and die}

Albeit quickly, it seems to me necessary to evoke a number of tendencies that, from the viewpoint of the people involved in these dynamics, contrast with the passions and movements induced by the fevers.

The comparisons with Uruaçu - the oldest municipality in the north of Goiás, a town that once had the same population as Minaçu, but that is much larger today - are suggestive of the particular circumstances that explain why particular localities and persons are more "affectable" by movements than others. Uruaçu is considered a more stabilized town, though, not only because of the presence of "farms" that have been there for decades, but also because "well-established folk" live there. Uruaçu, after all, is not like Minaçu, the latter being a place full of andarinos, "outsiders" and "single girls" (in the joke that does the rounds in the town, these young women need a poloque on their neck - one of those bells used on cattle to prevent them from becoming lost).

Minaçu itself is traversed by vectors that, resisting what seems so turbulent in fevers, help us to understand why this locality continues to exist - albeit precariously and at least for now. It is in this sense that we can comprehend the apparently contradictory local opinions concerning the asbestos mining company responsible for the emergence of the town in the 1960s. Known for its past cruelties and for the serious health problems that the mineral's extraction caused to its workers and Minaçu's residents as a whole, the company is nonetheless defended tooth and nail by the latter.

The epithet attributed to this company - known even today as the "mother of Minaçu" - sheds light on the native meanings concerning the economic movements that constitute this context (and other cases like it). In a universe marked by instability, movement and a constant to and fro - traits that help define the world as a native category (see Woortman 2009, Scott 2009, Vieira 2001) - the tie to the mother is seen to represent everything that is most solid and resistant. This perhaps helps us to understand the meaning of the gesture of those men deeply concerned to 
"leave something" for their children, and also why gold nuggets are so well suited to this purpose. These fathers - who are so frequently and easily attracted to the world (and to the fevers and the trecho), travelling far away from home, leaving behind children who will very often only have vague memories of them - "leave something" for their children too by leaving and abandoning them. They leave a memory, a nugget: something that is solid (and a contrast to the liquidity of gold dust or money), something that lasts. The accounts of the wives of miners who, through caricatures or stereotypes, dramatize the difference between men and women, provide a clear illustration of this peculiar "sexual division of labour". Men are the ones who lose their head and allow themselves to swept along by the euphoria or passion provoked by gold or fever. At such times little remains for women other than to lament or curse the husband revelling in a cabaré. In this context the mother signals a rooting that contrasts with the centrifugal elements of the world, a stability that opposes the ephemeral and voluble aspects of fever. In a world where almost everything is unstable and mobile, the importance of these mothers who remain, stay, do not leave, is undeniable: likewise the importance of what does not pass so quickly, what stays and lasts - like that which, in the words of Joseph Conrad, stays "waiting patiently for the passing away of this fantastic invasion".

Indeed, and even though they created interesting possibilities, the fevers passed in Minaçu (or "through" Minaçu): despite everything seen to be problematic about it, the company remained - and because it remained, the town itself still existed. "Just look at this road, look at the movement of cars coming here. Almost all this movement is due to the mining company. Were it not for it, almost nobody would appear in these parts!" Hence this company is capable of attracting people, vehicles, movement and money to Minaçu - and also of ensuring that these things do not abandon the town, or do not leave it quickly or for good. And just like so many of these women that I met - in the period of the fever and still today having to deal with these attractions and injunctions that impel men to go out into the world or ripping up (rasgando) the trecho - the mining company seems to possess the capacity to, almost literally, "hold it all together": a capacity to keep together, to impede, mitigate or ameliorate the dispersal of people and things, the general flight of everything and everyone through the world. After all, as the saying goes, someone without a mother is thrown into the world... 
But the stability offered by this company - just like the kind provided by any mother - is relative. Over the last few years, the beliefs and suspicions relating to the town "ending" have been further reinforced by the threats that the mining company will be forced to close its doors due to the national and international campaigns for a ban on the industrial use of asbestos. If things were already bad with the mining company in operation - people would frequently tell me - just imagine what will happen if it actually does have to close its doors...

It should be stressed, though, that while the fact that Minaçu "is coming to an end" causes dismay and concern, it does not necessarily cause surprise or astonishment. After all, for those involved in mining in the recent past, the memory of what took place in the brief gold boom in the same region at the start of the eighteenth century is still very much alive - or has been "revived" as a consequence of all these events. In the interval of two or three decades, towns and villages - São Félix, Arraias, Amaro Leite, Cavalcante - lived their days of buzzing activity only then to be abandoned or become almost entirely depopulated, "vanishing from the map" too. Of some of these towns, there remain today only "catacombs", "ruins" and "holes", the "sawdust of the pioneers" (casqueiros dos bandeirantes) still at the end of the twentieth century visited by those searching for signs of gold deposits (Palacin 1979, Póvoa Neto 1998).

For many of my interlocutors, indeed, this is a plausible and potential (albeit very often lamentable) fate for towns and localities: at some point, they simply end. At the entrance to Minaçu, a banner was unfurled and soon removed by the local council: "Visit Minaçu before it's over". The same expression was used in Campos Belos, a nearby municipality where, after the exhaustion of the emerald deposits, the population fell from 6,000 to 3,000 inhabitants in a short period of time.

But while this ending may mean "vanishing from the map" - repeating the fate of São Félix, for example - it may also signal a process prolonged in time in which everything and everyone gradually ceases to move, becoming increasingly stilled. Even the social movement of those affected by the dams, over recent years and in the opinion of some, has "frozen", becoming much less active and agitated than before. As I argued above, here we are dealing with movements and affects that fractally act simultaneously and analogously on persons, objects, relations and localities, situated on diverse and distinct 
planes and scales. If the correlate of a feverish town are feverish bodies and spirits, a stilled town is correlated with stilled lives, things and people.

Amarildo, a former miner, told me how he had been feeling over recent years, unemployed and no longer sure what to do to sustain his family. "Can you see that there?" - and he pointed to a rusty piece of equipment on top of a pile of sand, probably all that remained of a motor - "Stilled, stilled like that there. That's what I've been like these past few years, that is what my life has become". Certainly he is not stilled out of laziness or lack of effort: he is stilled because, irrespective of how much he had already gone after things, he is unable to provide any more. There is no one to help him: those of his colleagues and bosses still living in the town face the same dilemma - it was Minaçu too that stopped, today a town unable to provide a return for the efforts of its inhabitants. He lacks the option to leave: at the age of fifty with a stomach complaint and a large family to support, how could he venture into the world, looking for another place to live?

Confronted with this kind of situation, it should be emphasized that even in the recent past (in the gold fever, the cassiterite fever and the dam fever) people like Amarildo were able to engage in certain activities and behaviours that later vanished in stilled Minaçu: survival through their "own business" and the existence of conditions that enabled and even facilitated the circulation between different jobs and patrões (bosses). Moreover, the transitory nature of fever is itself responsible for the emergence of moneymaking possibilities that, from the viewpoint of my interlocutors, are absent from more "stabilized" situations. Without entering into detail here on such a complex point, I would simply emphasize that in these contexts of movement and agitation, people were able to take advantage of the "informal" character of many of the economic activities. Put otherwise: in these cases, the "formalization" of activities - that is, their submission to the regulations imposed by the papers and documents so important and problematic in the life of my interlocutors - had not yet occurred, nor made much headway into other areas of social life. Situations marked by movement invariably generate gaps and "market niches" whose exploitation by these kinds of people tends to be temporary: not only because they tend to become regulated over time (requiring paperwork that they are unable to obtain) but also because this regulation - from their point of view - is invariably linked to the arrival of firms or individuals with more capital who will begin to explore these 
opportunities "perennially". In relation to this "regulation", the arrival of the dams also had another impact in Minaçu, insofar as the presence of IBAMA (the Federal environmental protection agency) led to the emergence of the "environment" as an issue and the ban on extractivist practices that traditionally afforded non-monetized access to resources like game, fishing, timber collection, fruit harvesting and even small "urban" crops.

This stilled and dead Minaçu that I came to know was also, therefore, a more "regulated" and "formalized" town with a much greater presence of official agencies in people's lives. Not coincidentally, it was only recently that many of my interlocutors, for the first time in their lives, had sought to obtain documents such as identity cards and tax registration numbers. They did so in part because their physical survival became increasingly independent on government assistance: pensions, minimum income programs and staple food baskets, receipt of which requires the presentation of such documents.

\section{Mapping and hunting movement}

It should be clear, then, that in speaking about mobility we are not just talking about people. From the viewpoint of my interlocutors, instability and movement are attributes of things of the world. In this sense it is movement - "where is this town's movement?" - that is itself in movement, forever shifting and changing place.

Whether stilled like Amarildo cited above or living at the peak of the fever, these people make use of such movements in the constitution and dissemination of specific forms of knowledge. In Minaçu's rounds of conversation, the subjects privileged by participants indicate how almost everyone valorizes such knowledge - as specialists particularly interested in monetary flow, pondering and debating the circulation of income and the coming and going of resources, continually focusing their attention on signals that allow them to evaluate on what footing the town's movements (of money, but not only money) were, are and will be. Nobody there is unaware of what comes to pass (and what passes by) in the town's main avenue, the point of concentration and attraction of what remained of the movement in Minaçu.

The day I set foot there for the first time, I was asked a question that would be repeated throughout my stay. "So, you come from Rio de Janeiro 
then? What firm do you work for?" Concerned to make my purposes clear, I would invariably reply that I was linked to the university and there to carry out research. It was only towards the end of my field research that I realized that, by stating things in this way, I was suggesting to my interlocutors something quite different to what I intended. As I would discover over time, the people there have been familiar with visitors like myself for some time: someone white, educated, coming from a large urban centre to research a subject in places like Minaçu. In the hotel where I stayed during my first days in the field, I was in the company of other people with the same characteristics: but they were there to conduct mineral research. ${ }^{14}$ If local residents are always attent to the circulation of such people, it is because everyone knows that research work may announce the arrival of another large mining firm: "yeah, they say that Vale is arriving..."15

Researching those who conduct research, mapping the arrival and circulation of these outsiders, ficar curiando (pretending to be naïve, but listening carefully), learning about the rumours: a car with the logo of such-and-such company parked in the town centre, a truck without any identification drove past carrying prestigious and well-read people - and some person already become agitated. In an interview given to the local radio station, the mayor comments on his visits to Brasilia or Goiânia, can one really believe that he will bring these investments to Minaçu? "And if Minaçu is left with just the town council, you know how that will turn out..." The "town council" here refers metonymically to all the state resources passed onto the town. It is also for this reason that the idea of turning into a "town of pensioners" alarms the residents so much. Everyone knows what a town "without a firm" means. Many have been born in such places, or have passed

14 Certainly this is no mere coincidence. On the historical relationship connecting fieldwork in geology and anthropology, see Kuklick (1997).

15 “The excellent performance [of Goiás's mineral economy in the 200os] attracted the interest of various groups active in the sector that had turned their back on mineral exploration in the state. They returned in force. In 2004 the mighty Companhia Vale do Rio Doce (CVRD) alone [the company Vale mentioned in the above comment, a Brazilian form that is today one of the largest mining companies in the world] requested more than 200 permits from Goiás`s National Department of Mineral Production (DNPM) to explore the state's subsoil” (Galli 2007: 63). While I was still conducting my fieldwork in the north of Goiás, it was the town of Crixás founded during the eighteenth-century gold boom and since then experiencing an alternation between periods of ostracism and fever - which moved with the activities of the mining companies, even coming to be called "the Dubai of North Goiás": "The frenetic buzz of motorbikes, the lack of hotel vacancies, a throbbing commerce. The buzz typical of a large economic centre has taken over the apparent tranquillity of the Goiás municipality of Crixás, a little town of 15,100 inhabitants, 350km from Brasilia” (Correio Braziliense 2010). 
through them or lived in them for a while, or have family and acquaintances living there. The absence of movement also alarms people because it generates certain conditions that make the much feared and always possible return to captivity more probable: the return to a life marked by a lack of autonomy and freedom, like that experienced by their ancestors when they were living under the slavery system.

But as a result of their experiences too, my interlocutors were far from buying into the discourse propagated by these firms and politicians, remaining fairly sceptical about the solution promised by initiatives such as the arrival of Vale in Minaçu. Apparently more wary and less enthusiastic than the town's "elite", their ambitions on this matter were far more modest: rather than "progress" or "development", they dreamt of finding an odd-job or some temporary work, or obtaining more demand for the basic services they could offer should movement return to the town. ("Clothes washed. I make uniforms for firms in general. Rooms for rent. Builder and carpenter. Abelha Rainha Cosmetics Reseller. I do any kind of design. We paint chairs and tables. Sweets, cakes and savoury snacks sold. Popcorn Pete - parties and events".)

For the night guards and maids working in guest houses and hotels just as for their employers - the information and contacts obtained in these establishments seem to function as a supplement to their paltry wages: they found half a dozen muddy uniforms to wash, a job as a topography assistant in Minaçu itself, help for a brother trained as a drill operator to get a job on a project in Niquelândia, a tip concerning which places are hot right now.

These tips are also provided by those who are already working on the trecho and have returned to spend some days at home, or telephoned to advise about a job opportunity to be taken up without delay, as well as by travelling salesmen, truck drivers, dam construction workers, state employees or anyone who is roving the world and passing through Minaçu. As the movement is weak in this town, and while moving about and advancing there is increasingly complicated, it has also become more and more necessary - for those who are able to drift away or rove - to research and map what is happening elsewhere too. (Moreover these networks and techniques together with this readiness to leave smoothly (sair no liso) - that is, without any prolonged or prior preparations, with attitude and lightness - would seem to explain the absence in the town of the figure emblematically associated with the trecho: the gato (cat) or workforce recruiter, more 
often seen operating in rural communities and places less "mundane" and "accelerated" than Minaçu).

On a quick visit to people she knew in Rubiataba, town located a few hours from Minaçu, Aparecida used her time to learn more about the town's movement. She discovered that it was a "city without a firm" and that it also did not have any movements like the movement of people affected by dams, which guaranteed her a staple food basket each month. Aparecida also checked how much the local council paid its street cleaners: not only because she could do this job, it would also provide her with a parameter to measure the regional variations in the basic decent wage paid to workers without any qualifications or study. "No, best to forget for now this idea of leaving here just to be a bit closer to my sister..."

The techniques and knowledge used by miners to localize a deposit, a good boss or an ideal place to work seem to have been extended to other spheres, guiding the search for other opportunities and movements. Here the suggestion of Banaggia (2012: 42-3) is valuable: he suggests that the miners of Chapada Diamantina consider their activity "more akin to hunting than gathering". This is especially because the diamonds sought by the local miners "have their own life", "capable of moving about on their own free will". What is most interesting about this approximation to hunting - a term indeed widely used by this people, forever hunting for better, hunting their direction, hunting their destiny - is the idea that both those who search for something and the thing sought are in movement. (For people who are always on the move, "hunting" for movements is an imperative: but is it not also this "hunting" for movements which places people in motion?)

It needs to be remembered that frequent and "well informed" dislocations have always characterized the practice of mining. Among the institutions created with this purpose, we can highlight the rádio-peão or "worker radio", a native term for the informal networks through which information circulates that allows, after an area's decline, the miner to look for another place to work. ${ }^{16}$ Given the relations and passages existing

16 "It is no exaggeration to say that informal chat is one of the most important processes in gold mining. It broadly explains, for example, how the miners move from region to region with such ease, travelling distances that would seem immense to a European, but which a porcentista [miner working on a percentage basis] will regard just as nonchalantly as a carioca [a Rio de Janeiro resident] might contemplate a walk from Ipanema to Copacabana. Very often a miner without any experience of an area will travel with another miner who he met at another mine and who knows the area very well. Even when he travels alone, a miner will invariably have an idea 
between the universe of mining and that defined by the large construction works and projects, it is unsurprising that a rádio-peão is also found among the workers of the latter. For a specialist engineer in these projects (Corrêa 1987: 23-4), the latter is "one of the quickest means of communication existing on the face of the Earth [...] [and] it possesses an impressive speed and reliability. Everything is known through it". ${ }^{17}$

\section{Fevers and movements: surprising or familiar?}

Comparing Minaçu with other "more stabilized" towns, the reflections of my interlocutors were not very distant from those informed by the opposition cherished by rural and peasant studies in Brazil: namely the contrast between areas of long-standing occupation and the new or frontier zones.

In the discussions on the agricultural frontier of the 1970 and 80 os (e.g. Martins 1997, Velho 1981, 1979) or in the more recent debates concerning the effects of the advance of new frontiers of accumulation (e.g. Almeida 2010), this idea of "frontier" opens up a privileged space for considering various situations and phenomena in the light of questions not only relevant to the social sciences but also properly constitutive of them. Along these lines, we could suggest that such "frontier situations" have offered (and continue to offer) the researcher studying the Brazilian case the opportunity to accompany, in situ and through field work, phenomena that in other situations - in Western Europe or even in the USA say - can only be apprehended through historical accounts: Marx, in the famous Chapter XXIV of Capital, describes the aggressive process of expropriation that separates peasants from their means of production and uproots them from their traditional world, while simultaneously constituting land and work as commodities. The very geography of populating and occupying

of the best route, the best mines, and the kinds of problems likely to be encountered, through prior contact with a miner who worked in the region. This information is frequently very specific, including the names of hotels and owners with a good reputation. This makes the movement between the mining regions much less problematic" (Cleary 1992: 141).

17 On this point, the anecdote (or real story?) narrated by the same author is suggestive: "One time two engineers, to test the stealth and speed of this network of intrigues and rumours, scribbled on a sheet of paper the list of wages for recruiting employees at a non-existent project for maintaining, operating and lighting of the TransAmazonian highway [...] The wages proposed were something like five times the amounts typically paid in the region. They left the scribbled sheet on the meeting table in an envelope labelled 'confidential.' The next day, on arrival at the work site, there was an enormous queue of candidates looking to be hired [...],even presenting letters of recommendation from local politicians" (Corrêa 1987:23-24). 
the country, with its correlate formation as a nation state, helped visualize the advance of this "moving frontier" (Velho 1979: 14) over the immense remainder inexorably destined to be "integrated" and "civilized". From the Brazilian March Westward to state-directed colonization in Amazonia, passing through the creation of Brasilia and many other moments, there were also many who - even if silenced or ignored - described and denounced the violence and dramas unleashed by such processes. In our own way and emblematically, we have also therefore experienced the vicissitudes of "modernization".

In Marx and in so many other founders of sociological thought (Durkheim and Simmel being just two of the most obvious examples) the descriptions of this "modernization" seem to imply - somewhat tautologically - a "specific emphasis on rupture" that, according to Englund and Leach (2000: 227), "organizes, as ever in the discourse of modernity, the ways in which relevant research questions are identified and their potential answers circumscribed". Constitutive of sociology as a discipline and shaping a referential framework of crucial importance to the West's self-image, it is far from surprising that this "emphasis on rupture" has been subject to critiques from anthropologists and sociologists who, just like the latter, have sought to analyze - with some pertinence, I think - the analytic implications of its naturalization. Callon (1998: 39) argues, for example, that "there is no Great Divide between societies populated by calculative agencies and societies in which the agents do not calculate. Even Deleuze and Guattari were on the wrong track with their concept of deterritorialization, that extraordinary faculty bestowed on capitalism for breaking all ties and undoing solidarity". Maurer (2006: 16) meanwhile welcomes the recent production on the anthropology of money - the correlate and index par excellence of the "modernizing" or "capitalist" advances - since they furnish elements that contrast with that "same story of the "great transformation" from socially embedded to disembedded and abstracted economic forms", thereby allowing us to circumvent this "comforting plotline we are always expected to relate about the impact of money on 'traditional' societies and the dehumanizing and homogenizing effects of monetary incursions on all aspects of life in our own society".

Within the context of this very broad debate, my objective is modest. I have no intention of entering into the merits of the discussion concerning 
the existence or not of a "great transformation" or a "great divide". I merely wish to suggest how moments and situations of "rupture" have also been privileged in the descriptions and explanations pursued by the Brazilian social sciences in relation to places like Minaçu, however they have been (or are being) characterized. As the "outback", "frontier", the destination of "expansion fronts" or "pioneer fronts", an area submitted to the "effects of large-scale projects" or "deterritorialization", these locations and regions only seem to interest analysts to the extent that this encounter between the "traditional" and "modern" is re-enacted - an encounter where something like a "cultural contact" is produced "with the implications that previously impervious entities are suddenly in touch" (Des Chene 1997: 66).

I stress that I am not denying the existence of such an "encounter" - as authors like Maurer (2006) and Callon (1998) perhaps do - and much less the violence that invariably follows in its wake. In relation to Minaçu, it suffices to evoke the tragic fate of the Ava-Canoeiro indigenous groups occupying the region at the time of the construction of the Belém-Brasilia Highway and the arrival of the asbestos mining company in the 1950s. Albeit to a lesser extent, "cultural contacts" of this kind exist even today.

On the other hand, the current popularity of the concept of "deterritorialization" criticized by Callon (1998) suggests how "relevant research questions" (Englund and Leach 2000: 217) are usually identified and configured through this analytic tendency to look for and emphasize such "encounters", or to approach any modernizing initiative in the remote corners of the country through the analytic framework delineated by them. Without problematizing here this idea of an advance of "frontiers", we could say that the concern over what happens in them reveals more about the interest in studying the advance and expansion of phenomena supposedly definitive of "our" society - commodification, monetization, deterritorialization, civilization, modernization - than about the specific reality of those who are "steamrollered" by it. Consequently, those who have already been "deflowered" by these phenomena - having been reached by them in the past and today finding themselves distant, therefore, from the frontline of the "frontier" - seem incapable of offering the social scientist much in the way of attraction as an object of analysis. ${ }^{18}$ Here we encounter

18 The participants of the Minaçu movement of people affected by dams were not oblivious to the fact that after 
a modality of what Pina Cabral (2007: 95-6) denominates "cesurismo", characteristic of the "modernist social sciences" and their emphasis on the "discontinuity in change as the privileged 'moment' of our experience and our reflexive cognition of it”.

Here I am interested precisely in the "cognitive" dimensions implied by this kind of formula. If we really are presented with a situation in which certain people come face-to-face with such disruptive forces - all that is solid in their world melts into air "at a brutal and blinding speed" (Ferguson 1999:2) - then it falls to the anthropologist to ask how they conceptualize what is happening. Living through new or unknown experiences does not imply, of course, the incapacity to attribute meanings to them - preexisting cultural codes and schemes can encompass them or adapt to their apprehension. But even if this is the case, such an apprehension would be located far from what we would characterize as "knowledge" - or at least a consistent and consolidated form of knowledge of the kind discussed in the previous section.

Whether in relation to the sudden and tempestuous arrivals of economic booms and the "development" or decline that succeeds them, the people that I got to know are not surprised by such vicissitudes and alternations, or not anyhow to the point of experiencing the kind of "crisis in meaning" that, according to Ferguson (1999: 14), characterized the economic decline of the Copperbelt of Zâmbia (also an area of mineral exploration) where "the way that people are able to understand their experience and to imbue it with significance and dignity has (for many) been dramatically eroded" (Ferguson 1999: 14-15). While the mention of these "crises in understanding" or the "absence of meaning" exerts a clear dramatic (and political) appeal in terms of describing an undeniably revolting situation, they can also hinder the apprehension of the mechanisms used by those involved in these situations to explain such events.

For people like my informants, therefore, the appearance and disappearance of fevers is not exactly a novelty, nor indeed the turbulences, instabilities and dramas associated with them. Ironically, or even tragically, we could say that these phenomena are to some extent familiar to them. Here

some years in the spotlight, the Tocantins River Basin had become "forgotten" by the researchers and NGOs when the hydroelectric dams started to be built on the Madeira River - after the "occupation" of the Tocantins river by innumerable dams, Amazonia started to configured as the "new frontier" for energy production in the country. 
it is worth recalling that the categories fever and movement proved equally useful to describe and explain what happened both before (in the cassiterite and gold mining eras) and after the arrival of the dams.

But if the native perceptions and reflections concerning movements fail to match those formulas centred on the ruptures and irreversibilities correlated to them, they also do not fit the "familiarity" arising from the more or less "cyclical" succession, alternation and repetition of times (see Palmeira 2001, Dainese 2013) regulated by a seasonality (whether defined by the agricultural or religious calendar, or by the seasons of the year, or by elections).

One interesting possibility for dealing with this point comes from Velho (2007), who worked with rural workers from the Lower Tocantins - the same river that flows through the town of Minaçu, and the region of origin of many of my acquaintances. Analyzing the fears of a "return to captivity" among the local population, Velho argues that this formulation can be understood as the clear expression of a particular "notion of time" in which "the past and the present combine and come much closer together than the strictly linear notion (which, however, does not make it a cyclical notion)" (Velho 2007: 106). Inspired by the author's observations, I would say that in Minaçu the native perception of changes and transformations over time is strongly marked by the presence of processes, dynamics and encounters that become repeated and are present in different moments of time, always being liable to return. It is not exactly history that repeats itself but some of the movements that constitute it: the return of the fevers, the return of captivity, the return of these outsiders or "blond beasts" coming from the south, abroad or the coast (Guedes 2013a, Vieira 2001)... In speaking of a return, we are not therefore referring to a "great transformation" or to those supposedly unique and disruptive moments in which, for the first time, contact is established with unknown phenomena. Rather we are dealing with a people whose history - individual, familiar and even "communal" - is marked, among other things, by frequent encounters with modernizing agents and forces, and also by successive (and frequent) forms of pillaging.

I am unable to examine here all the implications of the importance attributed to the idea of return - whether for my interlocutors, or for academic discussions like the present. I merely emphasize that, for these people, the fever and the trecho constitute privileged spaces and times for knowing the world - whatever is harsh, turbulent and unexpected in the 
latter manifesting in a particularly striking manner in these circumstances, which also makes them such ideal "schools" (Rumstain 2009). As I looked to show elsewhere (Guedes 2013b: 338), we could claim therefore that, from the native viewpoint, "movement is necessary in order for knowledge and thought to exist". ${ }^{19}$ The belief and expectation that movements will be present - returning or able to be experienced elsewhere - thus anchor a "popular cosmopolitanism" (Guedes 2013b: 337-338) which seems to entirely contradict the widespread image of "peasants" or "communities" surprised by the "modernity" that suddenly irrupts within their previously tranquil and "traditional" worlds.

We can return then to our consideration of how social life is regulated in terms of times. Extracting some of the consequences of this, Palmeira (2001: 172) argues that, in this case, "social order is [...] perceived [...] in terms of adapting behaviours to particular ends posed at certain moments". Developing the author's suggestions, we could provisionally argue that - as occurs in the "time of the strike" (seen by the managerial sectors as "the clearest example of subversion") - the experiences of fever or the trecho are themselves "ordered" rather than being an expression of "social disorganization" or any modality of "derooting" or "deterritorialization". Clearly they are not that "ordered", their relative confusion and turbulence serving indeed to define them as a counterpoint to milder situations.

Making this claim is not to mitigate the seriousness or potential drama frequently involved in such modernizing projects. On the contrary, it recognizes that before the "arrival" of the latter, the people who are affected by the projects rarely experienced the "peasant", "community" or "traditional" idyll often suggested - consciously or not - by various analysts. In this sense, the importance attached by local people to movement suggests how forms of knowledge, practices or ways of life both express and are conditioned by a "worldview" in which the unstable, turbulent, ephemeral and provisional possess a singular cosmological centrality - an idea

19 Carneiro (2010) and Medeiros (2010) emphasized the same point in relation to other regions but dealing with universes geographically and culturally not very distant from my own. It was Rumstain (2009), on the other hand, who first explored the implications of the frequent statement among her interlocutors (migrants from Maranhão working on soybean plantations in Mato Grosso) that "the trecho teaches". Without giving much attention to this point, Woortman (2009: 219) had already pointed out in the 1980s how the experience of movement, via migration, constitutes a rite of passage for the male children of North-eastern rural workers: "To become a man it is necessary to confront the world [...] Having travelled makes people superior to those who have never left the place". 
confirmed by some of the native meanings attached to the notion of a world. It is through the acceptance - simultaneously and alternately tragic, fatalist and trecheira (i.e., "cunning") - that this is the way things are that this experience of "disorder" can itself be "ordered". Moreover, when this state of affairs is recognized and accepted, it becomes possible to make a virtue out of necessity - considering, like Sahlins (1997: 53), the reality of those "who knew how to extract, from ill fate, their [...] conditions of existence". Those same movements that unleash dramas and disturb so many lives - we can think, for example, of the dam-building fever that led to the obliteration of mining - are seen as opportunities to start again and make new investments, albeit provisional (see the case of the small traders who adapt to the new clientele, swapping the miners for dam construction workers) or elsewhere (as in the case of miners who were able to gain basic qualifications and enter the work market for the large-scale projects, following the movement across the rest of Brazil).

Furthermore while the native perspective presented here in discussing this point diverges somewhat from the narratives typically found in this recent sociological literature, it seems to me that we can still usefully compare them to other academic formulations that indicate just how old the experiences and phenomena discussed here may be. Here I have in mind the formulations used by historians and some of the prominent names of Brazilian social thought to describe, across a broader time span, the economic dynamic of the country or of some of its regions. Prado Jr. (1969: 186) for instance argues that this

evolution in jumps, through cycles that alternate in time and space, prosperity and ruin [...] summarizes the economic history of colonial Brazil [...] in each declining phase, a piece of the colonial structure is undone, the part of society affected by the crisis disintegrates. A more or less substantial number of individuals become ruined, lose their roots and the living basis of their subsistence. They begin to vegetate on the margins of the social order.

For Buarque de Holanda (1990: 71-2), meanwhile, these comings and goings of "an immense floating population, without a clear social position, living parasitically on the edge of regular and remunerated activities" is a direct consequence of the "intrinsic vices of the economic system of Colonial Brazil”. Mello e Souza (1995: 90), for her part, argues that the intense mobility 
characteristic of the country's interior populations, along with the instability inherent to their lives, can be seen to be a consequence of a colony of exploration destined to produce tropical crops whose commercialization favoured as much as possible the accumulation of capital in the hegemonic European metropolises. An economy with such a fragile and precarious base [...] was destined to drag down with it a large number of individuals, constantly affected by the fluctuations and uncertainties of the international market [...] It seems evident that the poor and even moderately wealthy population suffered greatly from this instability.

Discussing the role of the "missions to the interior" and the "civilizing" voyages to the "outback", Lima (1998: 74) claims that "repeated with Rondon is a theme widely present in Euclides da Cunha, in the reports of the expeditions made by the scientists of the Oswaldo Cruz Institute and in the literary work of Monteiro Lobato ${ }^{20}$ - the abandonment that follows bursts of progress, the image of the 'dead towns,' to employ the famous expression of the São Paulo writer".

\section{Conclusion}

The reference made above to Dainese (2013) is also interesting insofar as it reveals that the centrality - "cosmological" and "sociological", we could say attributed to the idea of movement is not limited to my interlocutors, which is of course unsurprising given the movements of the latter, today and in the past, through diverse areas of the country. Indeed we can note the recurrence of this category, as well as the variety of meanings that it assumes, in a series of recent works, focusing on the ways of life and thought of "outback" or "rural" Brazilian populations, especially in the north of Minas Gerais and in the states of Mato Grosso and Maranhão.

For Dainese (2011), movements regulate, signify and constitute not only the time of politics, but also the "affairs of the Church" (ibid: 175) and religious festivities, as well as the circulation between field and town - "lad, what are you going to do here? This town is a desert, let's go to the fields to see the movement" (ibid: 15) - and the visits and hospitality, so fundamental

20 Rondon (1922), Cunha (1966) and Lobato (1975) cited in Lima (1988). 
in this universe (ibid: 316 ). Even so (and in clear contrast to what happens in Minaçu), the people studied by this author perceive themselves as a "movement-less people" or "with little movement" - a "people who always lived [right there]" (ibid: 60).

In the research presently being conducted by John Comerford (personal communication) in the Jequitinhonha Valley, the moments of movement, revelry and festival are considered to be part of the holiday season - a period in which, as Mauss (2003: 473) had suggested, we also experience the kind of "alternation [of] the rhythm of concentration and dispersion" that so spectacularly shapes "the morphological organization" of the Inuit studied by himself. This is when the people return home who work afar - in the trecho, we could say - especially in coffee plantations in the West, in the Minas Gerais Triangle and in the interior of São Paulo. The movement of this period contrasts not only with the rest of the year in which many houses in the community remain closed but also with the somewhat stilled life of those who, far from home, lack the company of friends and family.

In the view of Carneiro (2010:45), the movement also produces a variety of effects. The continuous circulation of people between Buracos, in the north of Minas Gerais, "and the big world outside" helps us to understand why for the author's interlocutors - a "people brought together in the very act of dislocating themselves" - a "land [...] only exists in the movement of its "people". The effects of "animation" and "movement" are also recognized in the relation between food and prose: "in Buracos, offering something to eat enables the conditions for prose; it gives it movement, 'animation"' (ibid: 54); or in the joint work of the plantation, the "movement of people there" becomes an activity "making people", "an animator of people" and a "promoter of marriages" (ibid: 209) - "daily movement is what makes the 'people,' where plantation activity is both an index and a framework" (ibid: 213).

In the same region researched by Carneiro, both Andriolli (2011) and Medeiros (2011) studied different transformations caused by the creation of a National Park on the lives of groups previously living there. Evoking the importance of autonomy, considering this dimension in light of the commercial possibilities enabled by the "popular" and "informal" economies, the main interlocutor of Andriolli (2011) nostalgically evokes the "time of much movement" (ibid: 38 ): the "time of the elders", the "time of plenty, movement and freedom", the "time of the right to create" (ibid: 3 ), the "time of 
the freedom of the cowhand who, on the back of the horse and making money with their cattle, felt himself free of the ties of the boss" (ibid: 125). As in Dainese (2011), Medeiros (2011) argues that movement evokes the valorization of this sociability strongly based on "passing through" (ibid.: 38), "the movement between houses" that among other things ensures the "circulation of differences" (ibid: 44). Like Carneiro (2011), Medeiros (2011:46) also emphasizes the intrinsic relationship between movement and knowledge: "whoever doesn't walk doesn't know", the interlocutors of the former said. Meanwhile the latter takes as her working material those "narratives that privilege movement, in knowledge that is forged while one walks" (ibid: 94). Like my own acquaintances in Minaçu, Medeiros's interlocutors also contrasted the "stilled life" of the present with the "movement of the past" (2011: 74): "'the early time' was a period 'of much movement", "much less silent than now" (ibid: 68). Radicalizing the consequences of this "stilled life", Medeiros (2011: 161) emphasizes that the "lack of movement that affected people, cattle, plantation and fire, had repercussions not only for a 'society' based on roaming, but also for the 'nature' of the conservation unit" in question with local "biodiversity" itself coming under threat.

A more systematic comparison between all these cases still remains to be undertaken. Here the references to these works are intended to situate my argument better, drawing a contrast between the ethnographic literature relating to a particular "cultural area", the one in which my work is inserted, and the recent theoretical discussions concerning "mobilities". These discussions are largely anchored in a substantive and/or analytic association between such "mobilities" and a particular characterization of the contemporary world. Oriented by "a concern with diaspora, deterritorialization and the irregularity of ties between nations, ideologies and social movements", Appadurai (1996: 18) argues, for instance, that "this mobile and unforeseeable relationship between mass-mediated events and migratory audiences defines the core of the link between globalization and the modern" (ibid: 4). The reflections relating to these transformations will lead, Urry (2007: 6) suggests, to a "mobility turn [...] spreading in and through the social sciences, mobilizing analyses that have been historically static, fixed and concerned with predominantly a-spatial 'social structures."

As I have looked to show here, from the viewpoint of my interlocutors, movement, agitation or fever, rather than signalling a recent way of life or 
characterizing a novelty, are attributes of the world or life. Not that they are present all the time - or rather, not with the same intensity or strength: the instability and ephemerality implied by the idea of fever suggest just how "natural" are the alternations and reversals that, very often in a short space of time, lead a town like Minaçu to become depopulated, stop and end. In this sense, spatial mobility is also an expression of that "cosmological" mobility or something like a response or a form of adaptation to it.

Still in relation to the discussion of mobilities, we could equally turn to formulations such as those of Clifford (1997) and Ingold (2007) that, despite their many differences, emphasize the importance of problematizing - and not just in "contemporaneity" or "modernity" - the epiphenomenal or subordinate status of movement in the face of the primacy of more static realities. In evoking the importance of "dwelling-in-travel" and "travelling cultures", where "practices of displacement might emerge as constitutive of cultural meanings rather than as their simple transfer or extension" (Clifford 1997: 3), or arguing that journeys and walks should be thought of rather as "ways of being" (Ingold 2007: 75), these authors are much closer to the approach outlined here. Ingold (2007: 75) for example suggests that in order to comprehend "how people do not just occupy but inhabit the environments in which they dwell, we might do better to revert to paradigm of the assembly to that of the walk" (my italics).

We can return, then, to the point where we started, recalling the form through which my interlocutors made explicit the difficulties they were facing when I got to know them: after the construction of the dams, they told me that they could no longer walk. But we must also be cautious here, especially since - at least in this case - walking has to be understood not just in the narrow sense of spatial dislocation, but also in reference to other sorts of mobilities - "social" and "occupational", we could say - equally expressed by this formulation: not being able to walk also means not being able to advance, grow or improve in life or enjoy the kind of autonomy experienced by those who can abandon one occupation (and a boss) and search for another more appealing.

What the overlapping of these distinct meanings suggests is not only the "cosmological" centrality of movements, but also the fact that the latter provide a privileged code (or even a viewpoint) for these people to reflect on and talk about the world and their lives - and not only about 
themselves, since what is in play is something like a monist perspective in which everyone and everything can be conceived, fractally, through their movements. Reinvoking some of the topics discussed in this article, we can speak then of the more or less cyclical movements of economic power and decline, of the role assumed locally by what returns or what may return, and of waiting and the expectations relating to this; of the movements of feverish and passionate bodies in the hunt for gold, in the time of politics, in the cabarés and festivals; of the importance assumed by those resources and objects that never stop in people's hands (and others which, on the contrary, are zealously safeguarded and excluded from circulation); of what contrasts with agitation, passions and the volatile, looking to produce some form of duration or rooting, like the kind expressed by the (relative) stability provided by mothers; of the very movement of movement, stimulating people to set themselves in motion and leave stilled places in order to hunt for it; of these contexts in which instability, the to-and-fro and movement (which help to define the native sense of what the world is) are radicalized and taken to an extreme: the trecho and the fever...

Translated from the Portuguese by David Rodgers

Received October $24^{\text {th }}$., 2013, approved January $15^{\text {th }}$., 2014

\section{Bibliography}

ALMEIDA, Alfredo Wagner. 2010. “Agroestratégias e desterritorialização: os direitos territoriais e étnicos na mira dos estrategistas dos agronegócios”. In: A. Almeida et alli. Capitalismo globalizado e recursos territoriais: fronteiras da acumulação no Brasil contemporâneo. Rio de Janeiro: Lamparina. pp. 101-143.

AMORIM, Marcos Lourenço; DIAS, Francisca Gilliane Alencar. 2010. "Retratos falados das trabalhadoras sexuais de Coxim”. Revista Rascunhos Culturais, 1(1): 11-122.

ANDRIOLI, Carmem. 2011. Sob as vestes de Sertão Veredas, o Gerais. "Mexer com criação" no Sertão do IBAMA. Tese de Doutorado em Ciências Sociais, Instituto de Filosofia e Ciências Sociais / Unicamp - Campinas. ANTONAZ, Diana. 1995. Na escola dos grandes projetos. A formação do trabalhador industrial na Amazônia. Tese de Doutorado em Antropologia 
Social, PPGAS / Museu Nacional / UFRJ - Rio de Janeiro.

AQUINO, Napoleão Araújo de. 1996. A construção da Belém-Brasilia e a

modernidade no Tocantins. Dissertação de Mestrado em História, Faculdade de História / UFG - Goiânia.

BANAGGIA, Gabriel. 2012. As forças do jarê. Movimento e criatividade na religião de matriz africana da Chapada Diamantina. Tese de Doutorado em Antropologia Social, PPGAS / Museu Nacional / UFRJ - Rio de Janeiro.

BUARQUE DE HOLANDA, Sérgio. 1989. Raízes do Brasil. Brasília: Editora Universidade de Brasília.

BUARQUE DE HOLANDA, Sérgio. 1990. Monções. São Paulo: Brasiliense.

BUARQUE DE HOLANDA, Sérgio. 1994. Caminhos e fronteiras. São Paulo: Cia das Letras.

CALLON, Michael. 1998. "Introduction: the embeddedness of economic markets in economics". In: M. Callon (ed.), The laws of the market.

CARNEIRO, Ana Cerqueira. 2010. O 'povo' parente dos buracos: mexida de prosa e cozinha no Cerrado Mineiro. Tese de Doutorado em Antropologia Social, PPGAS / Museu Nacional / UFRJ - Rio de Janeiro.

CLEARY, David. 1992. A garimpagem de ouro na Amazônia: uma abordagem antropológica. Rio de Janeiro: Editora da UFRJ (English version: 1990. Anatomy of the Amazon gold rush. Iowa City: University of Iowa Press).

CLIFFORD, James. 1997. Routes. Travel and translation in the late twentieth century. Cambridge: Harvard University Press.

CORRÊA, Orlando J. D. 2007. Urrando no trecho. Recordações de um engenheiro de obras. Rio de Janeiro: Editora Corifeu.

CUNHA, Euclides da. 1966. Os Sertões: Campanha de Canudos. São Paulo: Aguillar

DAINESE, Graziele. 2011. Chegar ao cerrado mineiro: hospitalidade, politica e paixões. Tese de Doutorado em Antropologia Social, PPGAS / Museu Nacional / UFRJ- Rio de Janeiro.

DAINESE, Graziele. 2013. “Desentendimentos entre parentes: variações da intimidade". Unpublished. Cited with author's permission.

DES CHENES, Mary. 1997. “Locating the past”. In: A. Gupta e J. Ferguson (eds.), Anthropological locations: boundaries and grounds of a field science. Berkeley: University of California Press. pp. 66-85.

DIAS DUARTE, Luiz Fernando. 1986. Da vida nervosa nas classes trabalhadoras urbanas. Rio de Janeiro: Zahar. 
DURKHEIM, Emile. 2008. As formas elementares da vida religiosa: o sistema totêmico na Austrália. São Paulo: Paulus.

ENGLUND, Harri \& LEACH, James. 200o. "Ethnography and the metanarratives of modernity". Current Anthropology, 41(2): 225-48.

ESTEVAM, Luis Antônio. 2004. O tempo da transformação - estrutura e dinâmica da formação econômica de Goiás. Goiânia: Editora da UCG.

FERGUSON, James. 1999. Expectations of modernity: myths and meanings of urban life on the Zambian copperbelt. Berkeley/Los Angeles/London: University of California Press.

GALLI, Ubirajara. 2005. A história da mineração em Goiás: das primeiras lavras aos dias de hoje. Goiânia: UCG.

GARCIA, Marcos Roberto Vieira 2008. "Prostituição e atividades ilícitas entre travestis de baixa renda". Cadernos de Psicologia Social do Trabalho, 11(2): 241-256.

GASPAR, Elizete dos Santos. 1990. Os Bamburrados do Tapajós. Dissertação de Mestrado em Economia, Universidade Federal da Paraíba - Campina Grande.

GODELIER, Maurice. 2001. O enigma do dom. Rio de Janeiro: Civilização Brasileira.

GRZYBOWKSI, Cândido. 1987. Caminhos e descaminhos dos movimentos sociais no campo. Petrópolis: Vozes.

GUEDES, André Dumans. 2012. “Abrir no mundo, rasgando o trecho: mobilidade popular, família e grandes projetos de desenvolvimento". Cadernos de Campo, 21: 137-152.

GUEDES, André Dumans. 2013a. O trecho, as mães e os papéis. Etnografia de movimentos e durações no norte de Goiás. Rio de Janeiro: Garamond/Anpocs.

GUEDES, André Dumans. 2013b "Na estrada e na lama com Jorge, um brasileiro. Trabalho e moradia nas fronteiras do desenvolvimento". Horizontes Antropológicos, 19(39): 319-345.

GUYER, Jane. 2011. "Soft currencies, cash economies, new monies: past and present". Proceedings of the National Academy of Sciences of the United States of America, 109 (7): 2214-2221.

HIRSCHMAN, Albert. 1979. As paixões e os interesses: argumentos políticos a favor do capitalismo antes de seu triunfo. Rio de Janeiro: Paz e Terra.

INGOLD, Tim. 2007. Lines: a brief history. London: Routledge.

KUCKLICK, Henrika. 1997. "After Ishmael: the fieldwork tradition and 
its future”. In: A. Gupta e J. Ferguson (eds.), Anthropological locations. Boundaries and grounds of a field science. Berkeley: University of California Press. pp. 47-63.

LARETTA, Enrique. 2002. "Gold is illusion": the garimpeiros of Tapajós valley in the Brazilian Amazon. Stockholm: Stockholm Studies in Social Anthropology.

L'ESTOILE, Benoit de. 2014 “'Money is good, but a friend is better'.

Uncertainty, orientation to the future and 'the economy"'. Current Anthropology, 55 (S9): 1-12.

LIMA, Nísia Trindade. 1999. Um sertão chamado Brasil: intelectuais e representação geográfica da identidade nacional. Rio de Janeiro: Revan / Iuperj.

LINS RIBEIRO, Gustavo. 1988. Developing the Moonland: the Yacyreta hydroeletric dam and economic expansion in Argentina. PhD Thesis, Graduate Faculty in Anthropology, City University of New York - New York.

LINS RIBEIRO, Gustavo. 2006. El capital de la esperanza. La experiencia de los trabajadores en la construcción de Brasilia. Buenos Aires: Antropofagia.

LOBATO, Monteiro. 1957. Cidades mortas. São Paulo: Brasiliense.

MAGALHÃES, Sônia Barbosa. 2007. Lamento e dor: uma análise sócioantropológica do deslocamento compulsório provocado pela construção de barragens. Tese de Doutorado em Ciências Sociais, Programa de PósGraduação em Ciências Sociais / UFPA - Belém.

MARTINS, José de Souza. 1988. "Migrações temporárias. Problema para quem?”. Revista Travessia, 1: 27-32.

MARTINS, José de Souza. 1997. Fronteira. A degradação do outro nos confins do humano. São Paulo: Editora Hucitec.

MARTINS, José de Souza. 1998. “A vida privada nas áreas de expansão da sociedade brasileira” In: F. Novaes (org.), História da vida privada no Brasil - contrastes da intimidade contemporânea, vol. 4. São Paulo: Companhia das Letras. pp. 659-726.

MAURER, Bill. 2006. “The anthropology of money”. Annual Review of Anthropology, 35: 15-36.

MAUSS, Marcel. 1974. “Ensaio sobre a dádiva”. In: Sociologia e antropologia. São Paulo: Edusp. pp. 37-184.

MAUSS, Marcel. 2003. "Ensaio sobre as variações sazoneiras das sociedades esquimó”. In: Sociologia e antropologia. São Paulo: Cosac \& Naif. pp. 423-505.

MAZZAROLLO, Juvêncio. 2003. A taipa da injustiça. Esbanjamento econômico, dramasocial e holocausto ecológico em Itaipu. São Paulo: CPT/Edições Loyola. 
MEDEIROS, Camila Pinheiro. 2011. No rastro de quem anda: comparações entre o tempo do Parque e o hoje em um assentamento no noroeste mineiro. Tese de Doutorado em Antropologia Social, PPGAS / Museu Nacional / UFRJ - Rio de Janeiro.

MELLO E SOUZA, Laura. 2004. Os desclassificados do ouro: a pobreza mineira no século XVIII. Rio de Janeiro: Edições Graal.

NUNES, Heliane Prudente. 1985. A era rodoviária em Goiás: impactos na estrutura rural e urbana (1930-1961). Dissertação de Mestrado em História, Faculdade de História / UFG - Goiânia.

OLIVEIRA, Ariosvaldo Umbelino. 1989. "Paraíso e inferno na Amazônia Legal”. Revista Travessia - Fronteira Agrícola: Rasgando Terra e Lei, 1(2): 19-25. PALACIN, Luís. 1979. O século do ouro em Goiás. Goiânia: Oriente.

PALACIN, Luís; MORAES, Maria Augusta de Sant’Anna. 1989. História de Goiás. Goiânia: Editora UCG.

PALMEIRA, Moacir. 2002. "Política e tempo: nota exploratória”. In: M. Peirano (ed.), O dito e o feito: ensaios de antropologia dos rituais. Rio de Janeiro: Relume-Dumará. pp. 171-177.

PINA CABRAL, João de. 2007. "A pessoa e o dilema brasileiro: uma perspectiva anticesurista”. Novos Estudos CEBRAP, 78: 95-111. PÓVOA-NETO, Hélion. 1998. No caminho das pedras: itinerários na formação da mobilidade garimpeira em Goiás. Tese de Doutorado em Geografia, Departamento de Geografia / USP - São Paulo.

PRADO JR., Caio. 1969. Formação do Brasil contemporâneo. São Paulo: Editora Brasiliense.

RONDON, Cândido Mariano da Silva. 1922. Conferências. Rio de Janeiro: Typographia do Jornal do Commercio.

RUMSTAIN, Ariana. 2009. Peões no trecho. Estratégias de trabalho e deslocamento no Mato Grosso. Dissertação de Mestrado em Antropologia Social, PPGAS / Museu Nacional / UFRJ - Rio de Janeiro.

SAHLINS, Marshal. 1997. “O 'pessimismo sentimental'. Por que a cultura não é um 'objeto' em via de extinção”. Mana. Estudos de Antropologia Social, 3(1): 41-73.

SCOTT, Parry. 2009. "Famílias camponesas, migrações e contextos de poder no Nordeste: entre o 'cativeiro" e o 'meio do mundo"'. In: E. Godoi et alli., Diversidade do campesinato: expressões e categorias, v.2. São Paulo: Editora UNESP. pp. 245-268. 
SIGAUD, Lygia. 1988. "Efeitos sociais de grandes projetos hidrelétricos: as barragens de Sobradinho e Machadinho". In: L. Pinguelli et alli. (eds.), Impactos de grandes projetos hidrelétricos e nucleares. Aspectos econômicos, tecnológicos, sociais e ambientais. Rio de Janeiro: UFRJ/ COPPE. pp. 83-166. SIGAUD, Lygia; MARTINS-COSTA, Ana Luiza e DAOU, Ana Maria. 1987.

"Expropriação do campesinato e concentração de terras em Sobradinho: uma contribuição à análise dos efeitos da política energética do Estado". Ciências Sociais Hoje, 7(18): 241-290.

VELHO, Otávio. 1979. Capitalismo autoritário e campesinato. São Paulo: Difel. VELHO, Otávio. 1981. Frentes de expansão e estrutura agrária. Estudo do processo de penetração numa área da Transmazônica. Rio de Janeiro: Zahar Editores. VELHO, Otávio. 2007. “O cativeiro da Besta Fera”. In: Mais realistas que o rei. Ocidentalismo, religião e modernidades alternativas. Rio de Janeiro: Topbooks. pp. 103-134. (English version: 1991. "The peasant and the beast", European Review of Latin American and Caribbean Studies, no 51).

VIEIRA, Maria Antonieta da Costa. 2001. À procura das bandeiras verdes. Viagem, missão e romaria. Movimentos sócio-religiosos na Amazônia Oriental. Tese de Doutorado em Ciências Sociais, Instituto de Filosofia e Ciências Sociais/ Unicamp - Campinas.

WEINER, Annette. 1992. Inalienable possessions. The paradox of keeping while giving. Berkeley: University of California Press.

WOORTMANN, Klaas. 2009. "Migração, família e campesinato". In: C. Welch et alli, Camponeses brasileiros: leituras e interpretações clássicas, v.1. São Paulo: Editora UNESP. pp. 217-238.

ZALUAR, Alba. 2004. Integração perversa: pobreza e tráfico de drogas. Rio de Janeiro: FGV.

2010. "A Dubai do Norte Goiano". Correio Braziliense. Tuesday, July 6 ${ }^{\text {th }}$ 2010, p. 9. 